\title{
ZAGRANICZNE MIGRACJE KOBIET A PROBLEM RODZINY I MAŁŻEŃSTWA
}

\section{WPROWADZENIE}

Województwo opolskie, którego rozwój demograficzny, społeczny i gospodarczy warunkowany jest przebiegiem długotrwałych migracji zagranicznych, stanowi interesujące tło do ukazania skutków tych przemieszczeń ${ }^{1}$. Określane jest mianem regionu migracyjnego, jako że posiada interesujące cechy migracji zagranicznych i zajmuje wyjątkowe miejsce na mapie migracyjnej kraju. Charakteryzuje je duża liczba wyjazdów stałych, czasowych lub wahadłowych, które powodują utrzymujący się trwały odpływ migracyjny. Istotna jest $\mathrm{w}$ tym regionie masowa mobilność wynikająca $\mathrm{z}$ utrwalenia się silnych, zindywidualizowanych motywacji do wędrówek, z oswojenia migracyjnych więzi społecznych, wreszcie z ukształtowania się „,profesjonalizmu” migracyjnego w społecznościach, które tak jak ludność śląska - migracje traktuje jako sposób na życie. Istniejące tradycje migracyjne, sieci powiązań migracyjnych są wyznacznikami tego regionu ${ }^{2}$. Specjalne miejsce, jakie zajmuje Opolszczyzna na migracyjnej mapie Polski, wynika także z historycznie dość licznej grupy ludności autochtonicznej posiadającej prawo do obywatelstwa niemieckiego. Migracje na Opolszczyźnie jeszcze do niedawna dotyczyły przede wszystkim śląskich autochtonów z podwójnym obywatelstwem. W tym regionie do $2004 \mathrm{r}$. w procesie migracji brała udział

Dr hab. ANNA KRASNODĘBSKA - Instytut Nauk Pedagogicznych Uniwersytetu Opolskiego; adres do korespondencji: 45-052 Opole, ul. Oleska 48; e-mail: anna.krasnodebska@op.pl, ORCID iD: https://orcid.org/0000-0001-5451-1031.

${ }^{1}$ B. Solga, Miejsce i znaczenie migracji zagranicznych $w$ rozwoju regionalnym, Opole: Wydawnictwo Instytut Śląski 2013, s. 16.

${ }^{2}$ A. KRASNODĘBSKA, Migracja zarobkowa w ocenie kobiet z Opolszczyzny, w: Wspótczesne migracje: dylematy Europy i polski, red. M. Duszczyk, M. Lesińska, Warszawa: Wydawnictwo Ośrodek Badań nad Migracjami Uniwersytet Warszawski 2009, s. 128. 
głównie rodzima ludność śląska, która przed akcesją mogła legalnie pracować w Niemczech i innych krajach Unii Europejskiej. Wyjazdy odbywały się na zasadach zbliżonych do przepływów wewnąrzunijnych. Od momentu akcesji do struktur unijnych i otwierania się europejskich rynków pracy ten etniczny kontekst zjawiska nie jest już tak dominujący, ale nadal znaczące dla województwa opolskiego są gospodarcze i społeczne skutki migracji.

Ze względu na skalę zjawisk migracyjnych w tym regionie „Opolszczyzna może być traktowana jako Polska w pigułce i dostarczać szeregu cennych obserwacji dotyczących potencjalnych skutków współczesnych migracji Polaków"3. Następstwem migracji jest $\mathrm{z}$ jednej strony transfer pieniędzy zarobionych za granicą, a także wzrost jakości życia i zamożności rodzin migranckich. $\mathrm{Z}$ drugiej strony zostaje osłabiony potencjał rozwojowy spowodowany wyjazdem za granicę ludzi młodych, wykształconych, przedsiębiorczych ${ }^{4}$. Ważna jest sytuacja rodzinna osób migrujących i skutki migracji rodziców na życie ich dzieci.

Poakcesyjne migracje również $\mathrm{w}$ naszym regionie mogą być trwalsze niż wcześniejsze wyjazdy zarobkowe sprzed jednej czy dwóch dekad. Innymi przemianami zauważonymi $\mathrm{w}$ województwie opolskim $\mathrm{w}$ okresie poakcesyjnym są: „bardziej koniunkturalny i wypychający charakter migracji (w odróżnieniu od dorobkowej migracji przedakcesyjnej), większa skala emigracji zarobkowej z miast niż wsi oraz rosnący udział migrujących kobiet, stanowiących około połowy migrujących" ". Kobiety nie są już tymi, które towarzyszą w wyjazdach mężczyznom. Same stają się migrantkami, a „niezależne wyjazdy” traktują najczęściej w kategoriach zarobkowych. W przypadku kobiet i mężczyzn z województwa opolskiego zarejestrowano różne strategie migracyjne: u mężczyzn dominuje zatrudnienie na stałe w UE (54\% migrujących), a u kobiet ma miejsce okresowa migracja bez podejmowania pracy w Polsce (39\% $)^{6}$.

Podstawą niniejszych rozważań dotyczących migracji kobiet są wieloaspektowe badania własne prowadzone $\mathrm{w}$ środowisku kobiet wyjeżdżających do pracy za granicę ${ }^{7}$ Badania miały charakter ilościowy i jakościowy, w tym także obser-

${ }^{3}$ P. KACZMARCZYK, Studia przypadków, w: Wspótczesne procesy migracyjne w Polsce a aktywność organizacji pozarządowych $w$ obszarach powiązanych z rynkiem pracy. Raport FISE, red. P. Kaczmarczyk, J. Tyrowicz, Warszawa: Fundacja Inicjatyw Społeczno-Ekonomicznych 2008, s. 79.

${ }^{4}$ A. KRASNODĘBSKA, Aktualni i potencjalni migranci. Z badań w środowisku młodzieży szkót średnich i studentów województwa opolskiego, [Rozdział 7], w: Zmieniająca się rola migracji w rozwoju regionalnym, red. B. Solga, Opole: Wydawnictwo Instytut Śląski, Centrum Badań Migracji Zagranicznych 2009, s. 114.

${ }^{5}$ Spoteczne skutki poakcesyjnych migracji ludności Polski. Raport Komitetu Badań nad Migracjami Polskiej Akademii Nauk, praca zbior., Warszawa: Wydawnictwo Naukowe PWN 2014, s. 45.

${ }^{6}$ P. KacZmarczyK, Studia przypadków, s. 81.

${ }^{7}$ Wyniki tych badań były prezentowane we wcześniejszych tekstach. 
wacji uczestniczącej, zgodnie z zasadą triangulacji. Ilościowe prowadzone były za pomocą wywiadu kwestionariuszowego, który obejmował dwie kategorie kobiet: migrujących (357 osób) i niemigrujących $(167 \text { osób })^{8}$. W poszukiwaniach badawczych podjęto również badania jakościowe, w których wykorzystano listy-pamiętniki (30) oraz wywiady narracyjne (66). Listy były pisemnymi relacjami kobiet zgłaszającymi się w 2008 r. do konkursu, którego byłam inicjatorką. Konkurs na wspomnienia z pracy za granicą ogłoszono w gazecie regionalnej „Nowej Trybunie Opolskiej”. Trzydzieści anonimowych kobiet przesłało wspomnienia migracyjne na adres redakcji. Natomiast nagrywane wywiady narracyjne, trwające od 1 do 3 godzin, zapisywano zachowując oryginalny charakter wypowiedzi. Rozmówczyniami były osoby między 18 a 65 rokiem życia, z przewagą młodych kobiet w przedziale wiekowym 18-29 lat (42 kobiety). Kolejną grupę stanowily migrantki w wieku 30-40 lat (18 kobiet). Najmniej było kobiet w wieku 50-65 lat (6).

Odniosę się też do badań z 2014/15 r., prowadzonych w środowisku rodzin migranckich, a mianowicie do wywiadów pogłębionych w ramach projektu pt. „Więzi społeczne osób migrujących zarobkowo z Opolszczyzny. Światy tkanych i prutych więzi społecznych współczesnych Odyseuszy, Penelop i Telemachów"".

Uczestniczki badań jakościowych i ilościowych nie reprezentowały jednorodnego sposobu widzenia wartości i celów życiowych. Charakteryzowały się różnymi cechami społeczno-demograficznymi (wykształcenie, wiek, przynależność klasowa i kulturowa) ${ }^{10}$. Były wśród nich kobiety rdzennie związane ze Śląskiem Opolskim, urodzone w rodzinach pochodzących spoza Opolszczyzny lub też należące do tzw. rodzin mieszanych, gdzie rodzice, dziadkowie wywodzili się $\mathrm{z}$ różnych terenów, kultur. W badaniach uczestniczyły kobiety migrujące do różnych krajów Unii Europejskiej, takich jak: Niemcy, Holandia, Anglia, Irlandia, Włochy.

Wśród migrantek były kobiety aktualnie zatrudnione w kraju, wcześniej pracujące, ale także takie, które z różnych powodów nie podjęły pracy (brak kwali-

\footnotetext{
${ }^{8}$ A. KRASNODĘBSKa, Migracje i ich skutki w obszarze życia rodzinnego. Z doświadczeń opolskich migrantek, w: Wspótczesne polskie migracje: strategie - skutki społeczne - reakcja państwa, red. M. Lesińska, M. Okólski, Warszawa: Wydawnictwo Uniwersytetu Warszawskiego 2013, s. $156-177$.

${ }^{9}$ Projekt realizowany przez Teatr Lalki i Aktora w Opolu i Uniwersytet Opolski (Instytut Socjologii i Instytut Sztuki). Uczestniczyłam w pracach nad projektem, w prowadzeniu badań.

10 A. KRASNODĘBSKA, Znaczenie zagranicznych migracji zarobkowych $w$ ocenie kobiet z Opolszczyzny, „Studia Socjologiczne” 2009, nr 4, s. 257-258; TAŻ, Znaczenie pracy zawodowej $w$ ocenie migrantów pracujacych za granica. Refleksje z wybranych fragmentów badań dotyczacych migracji, „Humanizacja Pracy” 2015, nr 2(280), s. 174.
} 
fikacji, brak miejsc pracy na lokalnym rynku pracy, wiek itp.). Były to kobiety w wieku 18-65 lat. Wśród nich najwięcej było mężatek (60,27\%) i kolejno kobiet stanu wolnego (26,49\%), pozostałe kobiety to rozwódki $(6,91 \%)$ i wdowy (5,76\%). W zbiorowości migrantek $72,36 \%$ kobiet posiadało dzieci, a $27,26 \%$ to kobiety bezdzietne. W grupie badanych matek dominowały te posiadające dwójkę dzieci (32,25\%). 17,66\% matek miało jedno dziecko, 15,74\% - troje dzieci, a 6,91\% - więcej niż troje dzieci.

Badane respondentki reprezentowały kategorię migrantek w ruchu. Przejawiały postawy i dążenia charakteryzujące polskich migrantów jako „ludzi na huśtawce"11. Łączyło je doświadczenie wynikające z migracji i praca wykonywana poza granicami kraju. Każda z nich próbowała jednak wyrazić własny stosunek do pracy, rodziny, małżeństwa i ról, jakie pełni współczesna kobieta aktywna zawodowo. Każda $\mathrm{z}$ badanych określała się $\mathrm{w}$ tych różnych obszarach życia społecznego. Obszary te kryją podobne role i funkcje, jakie mogą lub muszą spełniać kobiety.

\section{ANALIZA TEORETYCZNA BADAŃ I ICH CELE}

Podejmując się analizy teoretycznej tych badań, sięgałam do teorii roli jako narzędzia do wyjaśnienia zjawisk. Modyfikuję ją poprzez dodanie innych, pozaludzkich (non-humans) partnerów roli, wobec których rola migrantki jest konstruowana i odgrywana ${ }^{12}$. W efekcie tego przekształcenia teoretycznego ustaliłam, że istnieje większa liczba partnerów roli, co jest ruchem symetrycznym wobec tego, jaki wykonał Bruno Latour. On ustanowił w teorii aktora-sieci (ANT) jako aktorów czynniki pozaludzkie, a ja ustanawiam je nie jako aktorów, ale jako partnerów roli, wobec których role są budowane ${ }^{13}$. Partnerami roli dla migrantek są rodzina, mąż, dzieci, sąsiedzi, pracodawcy, inni pracownicy, inni migranci, kobiety niemigrujące etc. Oprócz nich na tej pozycji uwzględniłam także pozaludzkich partnerów; dostrzegając ich i kategoryzując w postaci przestrzeni, dyskursów, praktyk, języka.

Teoretyczne ramy studiów własnych nad czynnikami socjokulturowymi aktywizującymi migrację zarobkową i jej konsekwencjami dla tożsamości kobiet, podejmujących czasową pracę na emigracji, określiłam za pomocą kategorii

${ }^{11}$ M. OKÓLSKI, Mobilność przestrzenna z perspektywy koncepcji migracji niepetnej, w: Ludzie na huśtawce. Migracje między peryferiami Polski i Zachodu, red. E. Jaźwińska, M. Okólski, Warszawa: Wydawnictwo Naukowe Scholar 2001, s. 11.

12 B. Latour, Splatajac na nowo to, co spoteczne. Wprowadzenie do teorii aktora-sieci, Kraków: Universitas 2010, s. 99-122.

${ }^{13}$ Tamże. 
„macierzyński” kapitał migracyjny. Jest to kapitał budowany przez kobiety poprzez ich ciężką pracę za granicą i ekonomiczną odpowiedzialność. Kobiety mają zidentyfikowane „obowiązki”, których wykonania oczekują ich partnerzy, dzieci i inni członkowie rodziny.

Na kapitale migracyjnym był budowany kapitał serca. Ta określona przeze mnie kategoria jest kategorią operacyjną. A sam kapitał serca jest produktem społecznego wizerunku, budowanym na podstawie posiadanych możliwości kobiet migrantek, wynikającym z zaangażowania emocjonalnego i prorodzinności ujawnianej szczególnie w obszarze pracy opiekuńczej na rzecz osób starszych, schorowanych czy nieletnich. Kapitał serca dotyczy również wypełniania zobowiązań wobec rodziny przez próbę łączenia pracy na emigracji z realizowaniem funkcji i ról rodzicielskich (transnarodowe macierzyństwo). Sprzyja on rekonstruowaniu roli matki odnośnie do różnych społecznych partnerów roli: dzieci i członków rodziny w kraju oraz partnerów w obszarze pracy migracyjnej. Pozwala w pracy migracyjnej i na rzecz własnej rodziny odnieść się do określonych praktyk, języka, dyskursu. Kapitał serca oparty jest na przekonaniu, że stosunek polskich migrantek do podopiecznych jest odmienny od tego wyrażanego przez inne osoby pochodzące $z$ kraju migracji. Towarzyszy jemu przeświadczenie, że oczekiwania pracodawców w kraju migracji są związane właśnie z wizją Polki uwikłanej w opiekę rodzinną i czynności na rzecz domu ${ }^{14}$. Ale również posiadającą oprócz sprawności manualnych, określone umiejętności interpersonalne oraz cechy psychologiczne wymagane $\mathrm{w}$ przypadku pełnienia chociażby roli opiekunki. Pojawia się przekonanie, że ważne w pracy opiekuńczej są nie tylko czynności fizyczne, ale też aktywność emocjonalna. Uznawane i doceniane przez innych jest obdarzanie podopiecznych ,naturalnymi uczuciami” przeciwstawnymi instrumentalnej postawie wobec uczucia. Wewnętrzne zasoby migrantek powodują, że wykonując pracę umysłową i fizyczną podczas sprawowania opieki nad ludźmi i działaniami na rzecz domu, czynią coś więcej, co Arlie Russel Hochschild nazywa pracą emocjonalną ${ }^{15}$.

Prezentując wybrane fragmenty moich badań odniosę się do myśli, emocji, wspomnień przedstawianych przez same migrantki. Uważam, że ważne jest ukazanie procesu migracyjnego, interpretacji zjawisk z perspektywy badanych kobiet.

Celem prowadzonych badań było rozpoznanie konsekwencji migracji dla tożsamości kobiety oraz kosztów podejmowania przez migrantki nowych ról

\footnotetext{
${ }^{14}$ A. KRASNODĘBSKa, Doświadczenia emocjonalne kobiet pracujacych za granica. Wspomnienia i refleksje migrantek z województwa opolskiego, „Opuscula Sociologica” 2013, nr 2, s. 56-58.

15 A.R. HochSCHILD, Zarzadzanie emocjami. Komercjalizacja ludzkich uczuć, Warszawa: Wydawnictwo Naukowe PWN 2009, s. 24.
} 
społecznych, poprzez odczytanie motywów, oczekiwań, jakie towarzyszą tego rodzaju wyjazdom. Pokazanie, jaki jest sposób widzenia siebie samej (tożsamość autorefleksyjna) przez kobiety migrujące $\mathrm{z}$ województwa opolskiego, a także ukazanie obrazu współczesnej mieszkanki Opolszczyzny migrującej za granicę w celach zarobkowych, poprzez wpływ doświadczeń migracyjnych na jej stosunek do pracy, do rodziny. Szczególnym celem moich badań było rozpoznanie, w jakim stopniu i w jakim zakresie na decyzje kobiet o wyjeździe do pracy za granicę wpływa ich poczucie obowiązku i odpowiedzialności za byt swojej rodziny, a w jakim autonomiczne dążenie do osobistego rozwoju, wymagające przekraczania granic lokalnego świata społecznego. Suma indywidualnych decyzji i postaw kobiet tworzy ważne dla regionu zjawisko społeczne.

W procesie zmian tożsamości istotne są punkty zwrotne, chociażby odgrywanie trudnych ról. Stąd ważne było odniesienie się do sytuacji przedmigracyjnej kobiet (do ich oceny dotychczasowej sytuacji życiowej, rodzino-zawodowej, do podejmowanych decyzji), do ich pobytu w kraju migracji i powrotów ${ }^{16}$. Jest to proces dynamiczny, w którym ma miejsce reorganizacja postaw.

\section{ZMIANY W RELACJACH MAŁŻEŃSKO-MACIERZYŃSKICH. ODCZUCIA TOWARZYSZĄCE MIGRANTKOM}

Bycie migrantką nie zawsze pozwalało kobietom na „luksus intensywnego macierzyństwa" ${ }^{17}$. Matki kreowały własne, indywidualne sposoby utrzymania więzi rodzinnych. Praktykowały swoistego rodzaju „miłość na odległość” nie tylko w stosunku do swoich partnerów, ale przede wszystkim do pozostawionych w kraju dzieci ${ }^{18}$. Pomocne stały się im nowe technologie i dlatego utrzymywały kontakt z bliskimi za pomocą SMS-ów, telefonów, e-maili. Kobiety poprzez codzienne rozmowy, wspólne święta, finansowe wsparcie wypracowywały czas dla rodziny i możliwość uczestniczenia w jej życiu ${ }^{19}$. Próbowały znaleźć alternatywę

16 A. KrasnodęBSKa, Migracje i ich skutki, s. 160-162; TAŻ, Doświadczenia emocjonalne kobiet pracujących za granica, s. 50-52.

17 S. URBAŃSKA, Matka migrantka. Pespektywa transnarodowości w badaniu przemian ról rodzicielskich, „Studia Migracyjne - Przegląd Polonijny” 35(2009), z. 1, s. 73.

${ }^{18}$ U. BECK, E. BECK-GERnSHEIM, Miłość na odległość. Modele życia w epoce globalnej, Warszawa: Wydawnictwo Naukowe PWN 2013, s. 151; A. KRASNODĘBSKA, Rodzina i praca w życiu opolskich migrantek, w: Rodzina i praca. Między tradycja a wspótczesnościa, red. U. Swadźba, E. Budzyńska, Katowice: Wydawnictwo Gnome 2010, s. 92.

19 R.S. PERREŇAS, Long distance intimacy: class, gender and intergenerational relations between mothers and children in Filipino transnational families, "Global Network" 2005, No. 5; A. KRASNODĘBSKA, Role kobiety w ocenie opolskich migrantek. Spojrzenie matek i córek, „Studia Migracyjne - Przegląd Polonijny" 39(2013), nr 2, s. 85-103. 
dla tradycyjnej roli matki ${ }^{20}$. Ich macierzyństwo zdawało się mieć postać transnarodową i nie łączyło się z jednym terytorium. Kobiety nie tylko pracowały za granicą, ale podczas każdego powrotu z migracji wykonywały działania na rzecz rodziny i domu. Przed wyjazdem organizowały życie domu oraz starały się zapewnić opiekę dzieciom. Brak jednego rodzica powodował, że jego rolę przejmował współmałżonek, partner. Sprawując opiekę na dzieckiem, rozmawiając $\mathrm{z}$ nim, był obecny w codzienności, pomagał rozwiązać problemy, co niekiedy przekładało się na relacje dziecka $\mathrm{z}$ tym nieobecnym rodzicem. Szczególnie dłuższy pobyt za granicą powodował, że dzieci czuły dystans wobec matki. Braku obecności matki w ważnych momentach życiowych dziecka nie zawsze udało się „nadrobić” w trakcie powrotów. Trudno było odbudować zaufanie dziecka i stworzyć poczucie intymnej bliskości. Nawet starsze dzieci miały żal do swoich matek i wypominały im ich wyjazd migracyjny ${ }^{21}$, zwłaszcza że dla niektórych z nich oznaczał on przejęcie ról (pomoc w obowiązkach domowych, opieka nad młodszym rodzeństwem). Wywoływało to u nich niezadowolenie i gniew. Dlatego migracja i powrót $\mathrm{z}$ niej wymagały od kobiet ponownego wejścia w rolę: żony, matki. Było to szczególnie trudne $\mathrm{w}$ sytuacji dłuższej rozłąki z rodziną, dziećmi. Ich przedłużająca się nieobecność, kiedy dzieci były małe, mogła utrudniać proces tworzenia się przywiązania ${ }^{22}$. Niejednokrotnie stawało się to podłożem wielu sytuacji stresowych, których konsekwencją były konflikty małżeńskie, trudności w nawiązaniu kontaktu z dzieckiem. Kobiety obawiały się, czy rodzina, szczególnie dzieci, poradzą sobie z tą czasową rozłąką. Dlatego starały się zorganizować odpowiednie dla dzieci środowisko wychowawcze. Pod ich nieobecność opiekę sprawowali inni członkowie rodziny. Tym samym miała miejsce konsolidacja i większa kooperacja rodzinna,

Sytuacja materialna, zawodowa kobiet i ich rodzin rzutująca na jakość życia samych migrantek i bliskich osób była ważnym czynnikiem wypychającym poza granice kraju. Ich wyjazd to sposób na realizowanie swych celów, ale przede wszystkich celów rodziny. Oto wypowiedź migrantki ukazująca charakterystyczne przyczyny wyjazdów do pracy za granicę: Decyzje o wyjeździe przyśpieszyła pogarszająca się sytuacja materialna zwiazana $z$ zaciagniętymi kredytami W domu sytuacja była nieciekawa i pieniadze byty pilnie potrzebne. Mieliśmy, co prawda, co do garnka włożyć, ale kredyty na dziatalność gospodarcza, jakie pobraliśmy w tamtym czasie, po prostu nas przerosty i z miesiąca na miesiąc się

${ }^{20}$ P. Hondagneu-Sotelo, E. Avila, ,I here, but I there”. The meanings of Latina transnational motherhood, „Gender and Society” 11(1997), No. 5, s. 548-571.

${ }^{21}$ A. KRASNODĘBSKA, Migracje zarobkowe a życie rodzinne kobiet z Opolszczyzny, „Pedagogika Społeczna” 2008, nr 3 (29), s. 76-77.

22 J. Bowlby, Przywiąanie, Warszawa: Państwowe Wydawnictwo Naukowe 2007. 
pogarszało. Dlugo takiej sytuacji byśmy nie udźwignęli. Interesy szły coraz gorzej i trzeba byto podjać pewne decyzje (49 K 53).

Brak zatrudnienia rodziców może wpływać na proces opiekuńczo-wychowawczy, może spowodować spadek poziomu życia rodziny, rezygnację z pewnych dóbr (np. jedzenie, odzież itp.). W konsekwencji przyczyniając się do osłabienia więzi wewnątrzrodzinnych. Pojawiają się konflikty małżeńskie i rodzinne wywołane trudną sytuacją ekonomiczną rodziny. Zmianie podlega ocena własnej osoby, co opisuje jedna z rozmówczyń: miałam tak niskie poczucie wartości ze względu na brak pracy (28 K 30).

Doświadczenia migracyjne kobiet ukazują potrzebę pogodzenia roli rodzinnej z rolą migrantki. Świadome nacisków i oczekiwań społecznych wobec ich obowiązków rodzinnych dzieliły się wątpliwościami, opisywały napięcia emocjonalne towarzyszące migracji. Wyjazd wymagał zmiany w przyjmowaniu i realizowaniu ról rodzicielskich. Konieczna stała się opieka nad pozostającymi w domu dziećmi, małżonkiem, ale także rodzicami. Szczególnie kobiety-matki odżegnywały się od dobrowolnego opuszczenia domu, dziecka, męża. To często nie był dla nich wolny i łatwy wybór. Dlatego kobiety, podobnie jak autorka jednego z listów, próbowały wyjaśnić, usprawiedliwić konieczność własnej mobilności. W ich relacjach można dostrzec walkę ze stereotypem wyrodnej matki migrantki. Nie można bezmyślnie krytykować i osądzać kobiet wychowujacych dzieci za to, że wyjeżdzaja do pracy daleko od domu. Życie niestety pisze różne scenariusze i nigdy nie wiadomo, co nas może jeszcze spotkać. A bez watpienia decyzja o wyjeździe do pracy za granice należy do jednej z najtrudniejszych $w$ życiu. $Z$ jednej bowiem strony taki wyjazd pomaga podreperować budżet domowy, a z drugiej częste $i$ dłuższe wyjazdy moga zniszczyć nawet najbardziej kochajaca się rodzinę (List nr 9). Kobiety zostały „wypchnięte” poza granice przez czynniki i okoliczności. Same niejednokrotnie za granicą opiekowały się innymi, gdy w tym czasie ich bliscy pozostawali sami. Towarzyszyła im obawa o dziecko, pojawiły się pytania, czy sobie poradzą, jak będą się sprawować ci, którzy mają być opiekunami na czas ich wyjazdu. One same jako wynajmowane opiekunki w kraju migracji otaczały „macierzyńską troską” dzieci, a także opiekowały się osobami starszymi, gdy czasami inne kobiety zajmowały się ich własnymi dziećmi. Pojawiają się tak zwane łańcuchy opieki (chains of care $)^{23}$.

Migrantki miały świadomość, że dzieci i inni członkowie rodziny bardzo tęsknią za nimi ${ }^{24}$. W badaniach prowadzonych za pomocą kwestionariusza wywiadu kobiety $(\mathrm{N}=524)$ stwierdzały, że wyjazd powoduje, że rodzina ciagle tęskni

\footnotetext{
${ }^{23}$ R.S. PARREŇAS, Long distance intimacy.

${ }^{24}$ A. KRASNODĘBSKA, Doświadczenia emocjonalne kobiet pracujących za granica, s. 53.
} 
$(\mathrm{M}=4,09)$, denerwuje się $(\mathrm{M}=3,34)$. Równocześnie wysoko oceniono fakt posiadania pracy: ciesza się, że mam prace zarobkowa $(\mathrm{M}=3,84)$. Zdaniem kobiet ich rodzina jest przekonana, że wyjazd za granice to konieczność $(\mathrm{M}=3,21)$ i że członkowie rodziny przyzwyczaili się do migracji $(\mathrm{M}=3,36)$. Takie oceny mogą być przekazem świadczącym o zdefiniowaniu na nowo własnej roli w rodzinie i na migracji. Migrantka jawi się jako osoba, która podjęła się wysiłku zarobkowania, a rodzina $\mathrm{w}$ kraju radzi sobie z zaistniałą sytuacją. Nadal jest bardzo silnie emocjonalnie związana $\mathrm{z}$ rodziną, $\mathrm{z}$ przestrzenią domu rodzinnego, dlatego w wielu relacjach podkreślana była wartość rodziny, uczucia wobec najbliższych oraz skutki rozłąki migracyjnej: Ja jestem osoba, dla której rodzina jest najważniejsza i dlatego każdy pobyt daleko od bliskich znositam bardzo źle, zawsze wracałam wycieńczona fizycznie i psychicznie (List nr 9). Kobiety podkreślały, że nie uczestniczą $\mathrm{w}$ życiu najbliższych osób. Tak było w przypadku matki dwóch córek, która stwierdziła, że: wyjazd spowodowat przede wszystkim to, że nie widziałam bardzo dużo rzeczy, jak dzieci dorastały, uczyly się różnych rzeczy (58 K 33).

Wyjazd za granicę i powrót do domu powodował, że związek między małżonkami, partnerami stawał się bardziej znaczącym. Wspominały o tym badane kobiety: Staliśmy się sobie bardziej bliscy, wiemy jak bardzo nam brakuje siebie (60 K 45); Jak wróciłam, bardziej doceniłam swój zwiąek. Na pewno określitabym to jako moja główna wartość (28 K 30).

Miłość na odległość, z którą mają do czynienia migrantki, może „uchodzić za wyższą formę romantyczności” ${ }^{25}$. Tym samym ,świat barier dla miłości przemienia się w świat okazji do miłości" ${ }^{\prime 26}$. Wypowiedź jednej z migrantek charakteryzuje tego typu zależność: Tak to jest moje i bardzo subiektywne odczucie, że to, jak każda rozłąka wzmacnia jakby, jakby to powiedzieć, taka później potrzebę, no poprawia te pewne relacje, bo człowiek się czuje stęskniony za soba i przynosi to, co czasami denerwuje. To później przynosi radość (r 6_Penelopa).

Kobiety, które migrują do pracy, w kraju pozostawiają rodzinę, współmałżonka i dzieci. Zdarza się, że zmienia się cały układ, starsi rodzice tracą możliwość opieki ze strony swoich dorosłych dzieci, dzieci tracą oparcie w rodzicach.

Zmienia się przestrzeń miłosnej tęsknoty. Zmienia się to, co dla badanych kobiet oznaczało wcześniej miłość, relacje z partnerem, intymność, seksualność. Przestrzeń, jaka ich dzieli, powoduje, że kontakt bezpośredni z partnerem, rodziną nie jest tak częsty. Wykorzystywanie w spotkaniach takich mediów, jak telefon, internet itp. powoduje, że kontakt jest pozbawiony wielu form zmysłowości.

\footnotetext{
${ }^{25}$ U. BeCK, E. BECK-GERnSHeIM, Miłość na odległość, s. 69.

${ }^{26}$ Tamże, s. 71.
} 
Jednak dla badanych kobiet staje się ważnym sposobem podtrzymywania więzi z bliskimi osobami, możliwością uczestniczenia w ich życiu codziennym. Potrzebna jest rytualność, aby utrzymać te wewnętrzne więzi. Niektóre badane stwierdzały, że porozumiewają się codziennie, o wyznaczonych godzinach. Rozmawiają przez telefon lub przez skype'a. Takie rozmowy to ważne praktyki podtrzymujące więź z najbliższymi, a także umożliwiające łączenie ról (matki, żony, córki zarabiającej za granicą) wypełnianych w przestrzeniach w kraju migracji i kraju pochodzenia. Wspomina o tym w liście jedna z migrantek: kontakt z rodzina, to dla nas jak balsam dla duszy. Po 5 minutach rozmowy z bliskimi bardzo nas uspokaja i dodaje sit (List nr 7). Kontakt telefoniczny czy za pomocą skype'a to wykorzystanie innego jeszcze partnera roli języka ojczystego, który jest nośnikiem prywatności, buduje ją w obcym otoczeniu. Można rozmawiać $\mathrm{z}$ rodziną, innymi bliskimi osobami i być wyłączoną na ten czas z roli ciężko pracującej migrantki lub na chwilę zawieszoną $\mathrm{w}$ tej roli. Wchodzi się $\mathrm{w}$ role matki, żony, córki itp. Poprzez język ojczysty jest się w tej roli bardziej intymnie. Język pozwala na kontynuowanie roli matki i bycie nadal ważną osobą w życiu rodziny.

Nie zawsze rozłąka migracyjna sprzyjała funkcjonowaniu związku. Świadomość potencjalnego zagrożenia można dostrzec w wypowiedzi jednej z kobiet: Po wielu latach pracy na zachodzie nie odczuwam, bym była mniej kochana osoba, co uważam za olbrzymi sukces, gdyż olbrzymia grupa naszych bliskich badź dalekich znajomych pozatracała się w tym rozczłonkowaniu rodziny (List nr 13). To zatracenie się, o którym pisała autorka cytowanego listu, mogło wynikać z braku bezpośrednich form intymności, rezygnacji ze zmysłowości, tęsknoty za bliską osobą oraz samotności. Samotność i poszukiwanie bliskości fizycznej powodowały, że migranci nawiazywali kontakty tak jak w telenowelach brazylijskich (34 K 27). Opisy kobiet ujawniały partnera roli, jakim są praktyki seksualne typu zdrada. O tego typu praktykach mówiono przede wszystkim w kontekście doświadczeń innych kobiet. Ale były także wypowiedzi opisujące własne zdrady. Dopuszczenie się praktyk typu zdrady małżeńskiej nie oznaczało „wyjścia" z roli, czy rezygnacji z pozycji małżonki, na co zwróciła uwagę jedna z rozmówczyń: Sa niektóre, które jada tam po prostu, żeby miło spędzić czas, poznać nowych mężczyzn, potem wracają do swoich zwiazków (27 K 51). Wśród migrantek były kobiety, które miały pretensje do swoich dotychczasowych partnerów. Za granicą poznały nowych partnerów i zdecydowały się na odejście od męża. Niektóre kobiety nie rezygnowały z poszukiwania towarzystwa na całe życie, ale nie chciały się godzić na źle funkcjonujący dotychczasowy związek (wyjeżdzam do pracy za granice z nowym partnerem i mam zamiar urodzić drugie dziecko (31 K 29). Ich odejście od mężów to efekt kryzysu dotychczasowego 
życia małżeńskiego, ale także możliwość rozwoju osobowego i zmiany w życiu rodzinnym. Pobyt za granicą stał się emocjonalnym rozrachunkiem tego, co było w kraju, w rodzinie, w małżeństwie, i sprzyjał budowaniu na nowo ról typu członek rodziny, współmałżonka. Był wyrazem dystansu do dotychczasowych praktyk i pełnionych ról.

Nie tylko odnotowano zmiany w relacjach małżeńskich. Migracyjny wyjazd prowokował do refleksji dotyczących związków i to tych istniejących, ale również potencjalnych. Oczekiwano większej wzajemności w codziennych działaniach na rzecz domu, rodziny. Młode, niezamężne kobiety projektując przyszły związek chcą partnerstwa. Część z nich, kiedy mowa o relacjach, stwierdza, podobnie jak cytowana migrantka: jeżeli chodzi o mój zwiq̨ek, to też bardziej partnerstwo niż w zwiąku mojej mamy (53 K 24).

Jednocześnie pewne praktyki i dyskursy mogą świadczyć, że kobiety są uwikłane w wiele ról, którym muszą sprostać. One same miały określony obraz kobiety i uważały, że powinna ona być partnerka życiowa $(\mathrm{M}=4,60)$, matka wychowująca i opiekujaca się dziećmi $(\mathrm{M}=4,54)$, decydująca o ważnych problemach rodziny $(\mathrm{M}=4,36)$, partnerka towarzyska $(\mathrm{M}=4,26)$, kierujaca domem $(\mathrm{M}=4,22)$, osobq tagodzaca konflikty $(\mathrm{M}=4,20)$, partnerka seksualna $(\mathrm{M}=4,18)$. Ich oceny świadczą o wielu oczekiwaniach, którym kobieta ma sprostać.

Rola migrantki i praca wykonywana za granicą powodowały, że kobiety zyskały w rodzinie miano tych, które się docenia, szanuje. Wcześniej ich nieodpłatna praca na rzecz własnej rodziny, domu nie była dostrzegana przez mężów i innych członków rodziny. Uważano, że ta przestrzeń prywatna (przestrzeń domu, mieszkania) jest tą przynależną kobiecie i to ona ma przede wszystkim wypełniać role wobec osób żyjących w tej przestrzeni.

Migracje były dla kobiet etapem rodzinnej biografii. Podczas nieobecności kobiet, to ich mężowie najczęściej przejmowali opiekę nad członkami rodziny i wypełniali bieżące obowiązki domowe. Po wyjeździe mężowie zaczęli doceniać swoje partnerki, odczuwając ich brak w życiu codziennym. Szanowali to, że żony zarabiają na rzecz domu i rodziny. Cieszył ich fakt przywożonych pieniędzy, a zarobki kobiet zmieniały podział ról, sprzyjały zaangażowaniu mężczyzn w opiekę nad dziećmi oraz cementowaniu małżeństwa. Taka sytuacja miała najczęściej miejsce w związkach o bardziej liberalnym charakterze. Jednak nie zawsze dobre zarobki kobiet przekładały się na uznanie małżonków/partnerów. Niektórzy z nich poczuli się niepewnie, gdyż ich żony pracując za granicą zarabiały więcej niż oni w kraju (Mojemu mężowi byto przykro, że pracując od rana do wieczora (więcej niż 8 godzin) mógt tylko pomarzyć o takich pieniadzach - List nr 13). Mogli sądzić, że tym samym będą one mieć więcej władzy, że zostanie 
zakłócona wcześniejsza stabilizacja, wsparcie i nasilą się konflikty. Pojawianie się tego typu zależności między partnerami mogło zwiększać ryzyko rozwodu.

\section{SPOSOBY FUNKCJONOWANIA RODZIN PODCZAS NIEOBECNOŚCI KOBIET. ŻYCIE CODZIENNE, PEŁNIONE FUNKCJE I ROLE}

W niektórych badaniach dotyczących wykonywania obowiązków domowych dostrzega się, że najmniej pracy domowej wykonują żonaci mężczyźni, zaś najwięcej kobiety zamężne. Podkreśla się, że brak równouprawnienia w pełnieniu ról i funkcji w obszarze domu jest efektem procesu socjalizacji rodzajowej: „kobiety wolą robić same wiele rzeczy, niż prosić męża o pomoc lub uważają, że nikt inny lepiej nie wykona od nich prac" ${ }^{27}$. Dla niektórych kobiet taką sytuacją zmieniającą dotychczasowe działania na rzecz domu i domowników stał się wyjazd migracyjny. Oto wypowiedź męża migrantki, który dokonuje oceny zmian W organizacji życia domowego: gorzej się żyje, dlatego że ja byłem przyzwyczajony... no jak żona nie pracowała za granica byłem rozpieszczony. Mówiąc krótko miałem wszystko przygotowane. Żona zreszta tak uważała, że to należy do jej obowiązków (r6_Penelopa).

Wykonywanie prac domowych może dawać kobietom poczucie sprawowania kontroli nad domową rzeczywistością, może dawać władzę w rodzinie. Czy tak jest rzeczywiście? Migrująca żona staje przed wyzwaniami typu: wypełnianie ról w obu przestrzeniach - tej w kraju migracji i kraju pochodzenia. Stara się wykonywać dobrze rolę opiekującej się domem w obu krajach.

Powroty kobiet z pracy migracyjnej do domu to reorganizacja przestrzeni domowej, jak i próby zawładnięcia nią i jej przedmiotami. Tego typu zależności dostrzegł mąż jednej z migrantek, tak to opowiedział: Ja sobie ustawiam na sport, a żona mówi „tyle mnie nie ma i Ty teraz program mi przestawiasz" (r6_ Penelopa). Negocjacjom podlegały także inne sfery dotyczące funkcjonowania domu, wychowywania dzieci.

Wyjazd powodował, że obowiązki przejmowali pozostający na gospodarstwie członkowie rodziny. Najczęściej byli to pozostający w kraju współmałżonkowie, dziadkowie, starsze rodzeństwo. Oto przykład zaangażowania się na rzecz domu najstarszej córki migrantki, która zobowiązała się pomagać ojcu $\mathrm{w}$ prowadzeniu gospodarstwa domowego: pamiętam, że wtedy bardzo mocno planowałam, że na przykład jak wróce ze szkoty to nie wiem, powiedzmy wtorki

${ }^{27}$ M. SIKORSKA, Nowa matka, nowy ojciec, nowe dziecko - o nowym układzie sit w polskich rodzinach, Warszawa: Wydawnictwo Akademickie i Profesjonalne 2009, s. 12. 
i czwartki będę gotować obiad. Musiałam nauczyć się takich rzeczy dosyć szybko, więc pamiętam, że razem z tata planowaliśmy podziat obowiąków i kto kiedy czym się będzie zajmowat (r1_Penelopa).

Niejednokrotnie przed wyjazdem to kobiety przygotowywały dom, domowników do funkcjonowania na czas ich nieobecności w kraju, wykonując czynności, o których wspominała jedna z migrantek: Przed wyjazdem nagotowatam im: córce i mężowi obiady, aby byli zabezpieczeni [...] Jak wracam do domu to robie generalne porzadki (32 K 55).

Organizacja życia rodzinnego migrantek ulegała pewnym modyfikacjom, spowodowanym nie tylko przejęciem obowiązków domowych przez pozostających w kraju, ale także zmianom na czas powrotu migrujących kobiet. Zdarzało się, że powrót matki, żony powodował zmiany w organizacji przestrzeni domu oraz w sposobie spędzania czasu wolnego. Prezentowana niżej wypowiedź córki migrantki świadczyć może nie tylko o odmiennym funkcjonowaniu domowników pozostających $\mathrm{w}$ domu, ale o wyobcowaniu się matki: wszyscy sobie już pouktadaliśmy życie $w$ pewien system, który nam pasowat. Ja się zajmuję tym $i$ tym, ktoś się zajmuje czymś innym i tak dalej, i tak dalej, i gdy mama wraca $z$ Wtoch czy wracała $z$ Wtoch, no to jakby burzy pewien system, bo wprowadza czlonka rodziny, którego jakby nie przewidujemy zazwyczaj(r1_Penelopa).

Wiele kobiet, kiedy wracało do domu starało się nadrobić zaległości związane $\mathrm{z}$ obowiązkami domowymi. Powrót $\mathrm{z}$ zagranicy bywał traktowany także w bardziej ceremonialny sposób. Matka migrantka tak opisywała zaangażowanie córki: Moja kochana córka przygotowała wspaniały obiad, upiekła ciasto, kupiła mi kwiaty (List nr 7).

\section{ZAKOŃCZENIE}

Wyjazd badanych kobiet do pracy za granicą był decyzją podjętą przez kobiety, ale także przez ich partnerów, czy innych członków rodziny. Kobiety stawały się migrantkami zarobkowymi, podejmując się wypełniania roli żywiciela rodziny. To im przydzielono rolę zarobkowej migrantki ${ }^{28}$. Wiele z nich obdarzonych odpowiedzialnością wobec pozostałych członków rodziny miało zrealizować określone cele, dążenia i zaspokoić potrzeby rodziny.

Pobyt za granicą oprócz namacalnych materialnych korzyści, możliwości poznania nowych krajów, ludzi, uzmysłowił wielu badanym kobietom, jak ważne

${ }^{28}$ E. GofFman, Spotkania. Dwa studia z socjologii interakcji, przeł. P. Tomanek, Kraków: Zakład Wydawniczy Nomos 2010, s. 119. 
jest to, co pozostawiają w swoim środowisku, w gronie rodziny, znajomych, ale także to, co się dzieje z nimi samymi. Wiele z nich wskazywało na zachowania, które są charakterystyczne dla osób wstępujących na drogę rozwoju osobistego, o których mówi C.R. Rogers ${ }^{29}$, a mianowicie poszukiwanie autentycznej, indywidualnej tożsamości, odchodzenie od ,powinności”, odkrywanie własnych potrzeb i celów; odchodzenie od spełniania czy zaspokojenia oczekiwań innych, sprawienia im przyjemności, zerwanie z konformistycznym sposobem zachowania narzuconym przez kulturę, czasami wręcz mocne pokazanie, że dotychczasowe oczekiwania to kwestia stereotypów.

Mimo stereotypowego dostrzegania kobiet z Opolszczyzny, jako osób zakotwiczonych w domu i wykonujących prace na rzecz domu, badane kobiety odchodzą od tego sposobu ich identyfikowania. Przyjmują rolę, która w danej sytuacji ma pierwszoplanowe znaczenie ${ }^{30}$. Stają się osobami zarobkującymi i aktywnymi zawodowo. Zdają się oczekiwać organizacji życia społecznego, pozwalającej uznawać potrzeby kobiet i mężczyzn za jednakowo ważne i stwarzającej warunki i możliwości pełnego rozwoju. Takie pragnienia szczególnie silnie towarzyszą młodym kobietom. One nie chcą tracić zbyt wiele z życia w różnych obszarach i nie sądzą, że mogą się spełniać jedynie w roli żony i matki. W większości badane kobiety starają się rozszerzyć zakres swojej roli o aktywność zawodową. Zdobyte zasoby finansowe mają dać i dają części kobiet możliwość pełniejszego rozwoju oraz bycia niezależną w szerszym wymiarze. Ale szczególnie matki wyjeżdżały, aby zapewnić dzieciom lepszą przyszłość: Mam mate dziecko, pochodzę z rodziny, gdzie nikogo nie byto takiego na kim można polegać [matka alkoholiczka]. Trzeba byto sobie samemu radzić $i$ chciałam mojemu dziecku stworzyć lepsze warunki do nauki, do podróżowania, poznawania (25K 29 lat).

Kobiety zostały zamknięte w ramy pozycji i zmuszone do urzeczywistnienia wpisanych $\mathrm{w}$ nią obietnic i wyrzeczen ${ }^{31}$. Usytuowanie w roli migrantki dla większości kobiet nie oznaczało rezygnacji z innych ról. Nadal utożsamiały się z tym, że są żonami, matkami, córkami, babciami. Były mocno osadzone w tych rolach, chociaż pobyt za granicą nie pozwalał im w pełni ich realizować. Będąc za granicą myślały o swoich bliskich (dzieciach, partnerach, rodzicach itd.), opowiadając o tym innym migrantkom. Uczestniczyły w jednym systemie ról, ale nadal były zaangażowane $\mathrm{w}$ sytuacje mające związek $\mathrm{z}$ rodziną. Nie rezygnowały z życia rodzinnego, z powinności macierzyńskich. Były kimś więcej niż tylko

\footnotetext{
${ }^{29}$ C. R. Rogers, O stawaniu się osoba, Poznań: Wydawnictwo Rebis 2002, s. 208-219.

${ }^{30}$ E. GofFMan, Spotkania, s. 126.

${ }^{31}$ A. GidDEns, Nowoczesność i tożsamość. „Ja” $i$ spoleczeństwo w epoce późnej ponowoczesności, Warszawa: Wydawnictwo Naukowe PWN 2001, s. 70.
} 
migrantkami zarobkowymi. Starały się poprzez różne strategie wypełniać te role, utrzymać kontakt z bliskimi za pomocą nowych mediów, a także poprzez cyrkulacyjne powroty. Przyjmowały rozstanie z rodziną, dziećmi decydując się na transnarodowe macierzyństwo. Sytuacje typu choroby w rodzinie, problemy wychowawcze z dziećmi, stawiały je przed dylematem.

Wiek mocno różnicował role migrantek. Część młodych kobiet bez własnej rodziny i związanych z nią rodzinnych zobowiązań traktowała wyjazd jako przygodę. Szczególnie one dostrzegały, jak ważne jest realizowanie się w pracy zawodowej. Zazdrościły swoim matkom, że mogły łączyć dwa obszary aktywności: rodzinę i pracę zawodową. One także mimo dystansu do roli pragnęły poważnie traktować związek i macierzyństwo. Jednak chciały bardziej niż ich matki skoncentrować się na własnej osobie. Podkreślały potrzebę własnego rozwoju, wykorzystania szansy, jakiej zdaniem niektórych migrantek nie miały ich matki, a niekiedy i one same.

W przypadku migracji kobiet można mówić o sytuacji ryzyka zachwiania tradycyjnych relacji w obszarze rodziny. Kobiety migrujące używały szeregu strategii, które ułatwiały im wypełnianie społecznych oczekiwań dotyczących ich ról w rodzinie, szczególnie roli matki. Badane kobiety postrzegały siebie jako dobre matki, dbające o egzystencję, przyszłość dzieci. Uważały, że poświęcając się i inwestując w potomstwo, stają się lepszymi matkami niż kobiety nieczyniące tego $^{32}$. Zmieniona została społeczna norma macierzyństwa $\mathrm{i}$ - jak zauważa M. Morokvasic - kobiety emigrantki z Europy Środkowo-Wschodniej chcą „sprostać ideałowi wywodzącemu się jeszcze z czasów socjalistycznych” ${ }^{33}$. Morokvasic nazywa ten ideał: „socjalistyczna dobra matka-superkobieta (socialist good mother superwoman)"34. Jest to kobieta zajmująca się dziećmi, domem, działająca na rzecz domu, a równocześnie pracująca zawodowo i wspierająca finansowo. D. Karjanen w stosunku do matek zarobkowych migrantek operuje określeniem „matka-migrantka-superkobieta” doświadczająca podwójnej pre$\mathrm{sji}^{35}$. Wiele badanych kobiet próbowało realizować ten ideał ${ }^{36}$. Doświadczały

\footnotetext{
${ }^{32}$ A. KRASNODĘBSKA Zagraniczne migracje zarobkowe kobiet z Opolszczyzny, s. 123-139; TAŻ, Migracje zarobkowe a życie rodzinne, s. 61-80.

${ }^{33}$ M. Morokvasic, Migration, Gender, Empowerment, w: Gender Orders Unbound: Globalisation, Restructuring and Reciprocity, red. I. Lenz, Ch. Ullrich, B. Fersch, Opladen \& Farmington Hills: Barbara Budrich Publishers 2007, s. 84.

${ }^{34}$ M. Muszel, Tradycyjna rola $w$ nietradycyjnej rodzinie. Transnarodowa migracja polskich żon i matek - studium przypadku, „InterAlia”. Pismo poświęcone studiom queer 2013, nr 8, s. 91-103.

35 D. KARJAnen, Gender, Race, and Nationality in the Making of Mexican Migrant Labor in the United States, „Latin American Perspectives” 35(2008), No. 1, s. 51-63; A. KRASNOdęBSKA,
} 
podwójnej presji starając się sprostać wymaganiom zawodowym stawianym w pracy na migracji i wymaganiom oraz obowiązkom rodzinnym. Miały poczucie winy, że nie uczestniczą w pełni w życiu swojej rodziny, zaniedbują obowiązki. Jednak zmieniały tradycyjny wizerunek kobiety i matki w rodzinie poprzez ekonomiczne wsparcie i transnarodową komunikację z dziećmi ${ }^{37}$. Relacje wielu kobiet świadczą, że nie tkwią one w układzie patriarchalnym i odchodzą od stanu udomowienia. Ich aktywności zawodowej na emigracji i w kraju towarzyszy zmiana ról społecznych i systemu wartości. Mają potrzebę łączenia w sposób harmonijny pracy zawodowej oraz życia osobistego (work-life-balance $)^{38}$. Zdają sobie sprawę, że na rodzinę można spojrzeć w sposób tradycyjny, ale też z perspektywy modeli alternatywnych form rodziny ${ }^{39}$.

Ich doświadczenia migracyjne sprzyjają widzeniu rodziny, w której zmieniają się stosunki między jej członkami, a relacje małżeńskie nabierają charakteru równości i mogą opierać się na więzach emocjonalnych.

\section{KONKLUZJE}

- Praca migracyjna kobiet staje się tradycją rodzinną, do której przyzwyczajają się pozostali członkowie rodziny. Status migrantki może powodować, że jest się wzorem dla dzieci, które wybierają podobną drogę i decydują się na wyjazd za granicę. Dlatego wśród badanych kobiet były matki i córki. Można stwierdzić, że w wielu rodzinach migranckich da się zaobserwować pewien trend dziedziczenia rodzinnego stylu życia, w który jest wpisana rozłąka z powodów ekonomicznych.

- Trudno jednoznacznie stwierdzić, ile z wyjeżdżających czasowo do pracy kobiet zdecyduje się na pozostanie na stałe za granicą. Wśród badanych były migrantki od wielu lat jeżdżące do pracy. Niewiele z nich mogło powrócić do kraju. Te, które na to się zdecydowały, tłumaczyły to dużym ryzykiem. Większość migrantek podjęła je, mocno przeżywając sytuacje zaistniałe w ich domach (choroba członków rodziny, problemy wychowawcze z dziećmi).

Role kobiety w ocenie opolskich migrantek, s. 96-97; M. MuSZEL, Tradycyjna rola w nietradycyjnej rodzinie, s. 91-103.

${ }^{36}$ A. KRASNODĘBSKA, Role kobiety w ocenie opolskich migrantek, s. 96-97.

37 R.S. PARreñas, Long-Distance Intimacy, s. 317-336; A. KRASnOdęBSKA, Role kobiety w ocenie opolskich migrantek, s. 96-98.

${ }^{38}$ A. KRASNODĘBSKA, Migracje i ich skutki w obszarze życia rodzinnego, s. 168; TAŻ, Role kobiety w ocenie opolskich migrantek, s. 85-103.

${ }^{39}$ T. SZLENDAK, Socjologia rodziny. Ewolucja, historia, zróżnicowanie, Warszawa: Wydawnictwo Naukowe PWN 2010, s. 457-466. 
- Migrujące kobiety, pragnąc być razem ze współmałżonkami, z dziećmi, decydowały się na rodzinną emigrację (emigrację definitywną). U części kobiet pojawiał się problem adaptacji ich dzieci do nowych warunków ${ }^{40}$. Dla niektórych wyjazd staje się okazją do porzucenia dotychczasowego partnera i założenia nowej rodziny w kraju migracji.

- Badane kobiety próbowały zmienić sytuację materialną własną i rodziny. Ale ważna była też próba odnalezienia siebie, poznanie świata, bycie w nim, odkrywanie siebie dzięki innym, odkrywanie na nowo samej siebie, czasami powrót do korzeni. Opolskie kobiety wydawały się zgadzać z tym, co podkreślała A. Kłoskowska, że „uczestnictwo w narodowej wspólnocie nie pochłania i nie wyczerpuje całego człowieka. Jest on ponadto członkiem innych wspólnot, wielu innych zbiorowości, grup celowych i społeczności”41.

\section{BIBLIOGRAFIA}

BeCK U., BeCK-GeRnsheim E.: Miłość na odległość. Modele życia w epoce globalnej, Warszawa: Wydawnictwo Naukowe PWN 2013.

Bowlby J.: Przywiązanie, Warszawa: Wydawnictwo Naukowe PWN 2007.

GidDENS A.: Nowoczesność i tożsamość. „Ja” i społeczeństwo w epoce późnej ponowoczesności, Warszawa: Wydawnictwo Naukowe PWN 2001.

Goffman E.: Spotkania. Dwa studia z socjologii interakcji, przeł. P. Tomanek, Kraków: Zakład Wydawniczy Nomos 2010.

HochSCHILD A.R.: Zarządzanie emocjami. Komercjalizacja ludzkich uczuć, Warszawa: Wydawnictwo Naukowe PWN 2009.

Hondagneu-Sotelo P., Avila E.: „I here, but I there”. The meanings of Latina transnational motherhood, „Gender and Society” 11(1997), No. 5, s. 548-571.

KACZMARCZYK P.: Studia przypadków, w: Współczesne procesy migracyjne w Polsce a aktywność organizacji pozarządowych w obszarach powiązanych z rynkiem pracy. Raport FISE, red. P. Kaczmarczyk, J. Tyrowicz: Warszawa: Fundacja Inicjatyw Społeczno-Ekonomicznych 2008.

KŁOSKOWSKA A.: Kultury narodowe u korzeni, Warszawa: Wydawnictwo Naukowe PWN 1996.

KraSnOdęBSKA A.: Migracja zarobkowa w ocenie kobiet z Opolszczyzny, w: Współczesne migracje: dylematy Europy i polski, red. M. Duszczyk, M. Lesińska, Warszawa: Wydawnictwo Ośrodek Badań nad Migracjami Uniwersytet Warszawski 2009.

KraSNODĘBSKA A.: Migracje i ich skutki w obszarze życia rodzinnego. Z doświadczeń opolskich migrantek, w: Współczesne polskie migracje: strategie - skutki społeczne - reakcja państwa, red. M. Lesińska, M. Okólski, Warszawa: Wydawnictwo Uniwersytetu Warszawskiego 2013.

${ }^{40}$ A. KRASNODĘBSKA, Sytuacje adaptacyjne dzieci polskich emigrantów w Norwegii, „Roczniki Nauk Społecznych" 5 (41) 2013, nr 4, s. 51-65.

41 A. KŁosKowska, Kultury narodowe $u$ korzeni, Warszawa: Wydawnictwo Naukowe PWN 1996, s. 103. 
KRASNODĘBSKA A.: Znaczenie zagranicznych migracji zarobkowych w ocenie kobiet z Opolszczyzny, „Studia Socjologiczne” 2009, nr 4, s. 251-272.

KRASNODĘBSKA A.: Znaczenie pracy zawodowej w ocenie migrantów pracujących za granicą. Refleksje z wybranych fragmentów badań dotyczących migracji, „Humanizacja Pracy” 2015, nr 2(280), s. 163-176.

KRASNODĘBSKA A.: Doświadczenia emocjonalne kobiet pracujących za granicą. Wspomnienia i refleksje migrantek z województwa opolskiego, „Opuscula Sociologica” 2013, nr 2(4), s. 47-64.

KRASNODĘBSKA A.: Rodzina i praca w życiu opolskich migrantek, w: Rodzina i praca. Między tradycją a współczesnością, red. U. Swadźba, E. Budzyńska, Katowice: Wydawnictwo Gnome 2010.

KRASNODĘBSKA A.: Aktualni i potencjalni migranci. Z badań w środowisku młodzieży szkół średnich i studentów województwa opolskiego, [Rozdział 7], w: Zmieniająca się rola migracji w rozwoju regionalnym, red. B. Solga, Opole: Wydawnictwo Instytut Śląski, Centrum Badań Migracji Zagranicznych 2009.

KRASNODĘBSKa A.: Role kobiety w ocenie opolskich migrantek. Spojrzenie matek i córek, „Studia Migracyjne - Przegląd Polonijny" 39(2013), nr 2, s. 85-104.

KRASNODĘBSKA A.: Migracje zarobkowe a życie rodzinne kobiet z Opolszczyzny, „Pedagogika Społeczna" 2008, nr 3 (29), s. 61-80.

KRASNODĘBSKA A.: Sytuacje adaptacyjne dzieci polskich emigrantów w Norwegii, „Roczniki Nauk Społecznych" 5 (41) 2013, nr 4, s. 51-65.

LATOUR B.: Splatając na nowo to, co społeczne. Wprowadzenie do teorii aktora-sieci, Kraków: Universitas 2010.

MoroKvASIC M.: Migration, Gender, Empowerment, w: Gender Orders Unbound: Globalisation, Restructuring and Reciprocity, red. I. Lenz, Ch. Ullrich, B. Fersch, Opladen \& Farmington Hills: Barbara Budrich Publishers 2007.

Muszel M.: Tradycyjna rola w nietradycyjnej rodzinie. Transnarodowa migracja polskich żon i matek - studium przypadku, „InterAlia”. Pismo poświęcone studiom queer 2013, nr 8, s. 91-103.

OKÓLSKI M.: Mobilność przestrzenna z perspektywy koncepcji migracji niepełnej, w: Ludzie na huśtawce. Migracje między peryferiami Polski i Zachodu, red. E. Jaźwińska, M. Okólski, Warszawa: Wydawnictwo Naukowe Scholar 2001.

PERREŇAS R.S.: Long distance intimacy: class, gender and intergenerational relations between mothers and children in Filipino transnational families, „Global Network” 2005, No. 5, s. 317-336.

Rogers C.R.: O stawaniu się osobą, Poznań: Wydawnictwo Rebis 2002.

SiKORSKA M.: Nowa matka, nowy ojciec, nowe dziecko - o nowym układzie sił w polskich rodzinach, Warszawa: Wydawnictwo Akademickie i Profesjonalne 2009.

SolgA B.: Miejsce i znaczenie migracji zagranicznych w rozwoju regionalnym, Opole: Wydawnictwo Instytut Śląski 2013.

Społeczne skutki poakcesyjnych migracji ludności Polski. Raport Komitetu Badań nad Migracjami Polskiej Akademii Nauk, praca zbior., Warszawa: Wydawnictwo Naukowe PWN 2014.

SzLENDAK T.: Socjologia rodziny. Ewolucja, historia, zróżnicowanie, Warszawa: Wydawnictwo Naukowe PWN 2010.

URBAŃSKA S.: Matka migrantka. Pespektywa transnarodowości w badaniu przemian ról rodzicielskich, „Studia Migracyjne - Przegląd Polonijny” 35(2009), z. 1, s. 61-84. 


\section{ZAGRANICZNE MIGRACJE KOBIET A PROBLEM RODZINY I MAŁŻEŃSTWA}

\section{Streszczenie}

W artykule na podstawie badań jakościowych (wywiady, listy) i ilościowych przedstawiono refleksje i wspomnienia kobiet migrantek dotyczące ich rodzin i małżeństwa. Podejmując się analizy teoretycznej tych badań, wzięto pod uwagę teorię roli jako narzędzie do wyjaśniania zjawisk. Teoria ta została zmodyfikowana poprzez dodanie innych, pozaludzkich (non-human) partnerów roli, wobec których rola migrantki jest konstruowana i odgrywana. Wyjazd za granicę nie rozwiązuje konfliktu między rolami rodzinnymi, małżeńskimi a zawodowymi, może go jedynie nasilać.

Słowa kluczowe: migracje kobiet; rodzina; małżeństwo; konstruowanie ról

\section{FOREGIN MIGRATIONS OF WOMEN \\ FAMILY AND MARRIAGE PROBLEM}

\section{$\mathrm{Sum}$ m a r y}

The article, based on qualitative research (interviews, letters) and quantitative research, presents reflections and memories of migrating women about their families, a marriage. Taking a theoretical analysis of these studies the used the theory of the role as a tool to explain the phenomena. This theory has been modified by adding other non-human partners. of the role to which the role of the feminine migrant is constructed and played. Going abroad does not solve the conflict between the family, marriage and professional roles of women, it can only intensify it.

Key words: the migration of women; family; marriage; construction of roles 